\title{
Teaching English through English: Exploring Anxiety in Non-native Pre-service ESL Teachers
}

\author{
Tecnam Yoon \\ Department of Teacher Education and Curriculum Studies, School of Education, University of Massachusetts, Amherst, \\ USA \\ Email: tyoon@educ.umass.edu
}

\begin{abstract}
The purpose of this study is to investigate the sources of foreign language anxiety experienced by non-native pre-service ESL teachers (NNPSET) in licensure program. 52 pre-service ESL teachers enrolled in a public university in Seoul, South Korea, participated in this study during their teaching practicum as part of requirement to pursue ESL licensure. 52 participants completed a 24-item modified survey based on Foreign Language Classroom Anxiety Scale (FLCAS) in order to figure out 1) which language anxiety factors would be the most influential among NNPSETs in their English practicum, and 2) which language anxiety factors strongly affect NNPSETs when they conduct micro-teaching sessions. The Principal Component and principal axis factoring tools were used to analyze the data of the survey. The results indicate that $\mathbf{4}$ major factors were found which affected NNPSETs language anxiety on the classroom situation. The most influential factor of all was clustered with Factor 1 - 'Language anxiety on using English in the class'. And the other three factors were identified as 'Language anxiety based on self-confidence', 'Language anxiety about class preparation', and 'Language anxiety overcome with efforts'.
\end{abstract}

Index Terms — affective domain, student teachers, foreign language anxiety

\section{INTRODUCTION}

It is clear that foreign and second language anxiety is a complex psychological factor to both its learners and teachers. Most research has already proved that foreign language production, improvement, and achievement can be impeded by the emotional symptoms of anxiety (Horwitz, 1988; Horwitz, 2001; Horwitz \& Cope, 1986; Horwitz \& Young, 1991; Huang, Eslami \& Hu, 2010; Hussain, Shahid \& Zaman, 2011; Liu and Jackson, 2008; Liu \& Zhang, 2010; Macintyre \& Gardner, 1989; Macintyre \& Gardner, 1991; Ohata, 2005).

In particular, when it comes to a case of the pre-service ESL teachers who definitely lack of enough formal classroom teaching experience, let alone English language proficiency, the level of anxiety that they feel must be even higher as opposed to skillful ESL teachers. Moreover, supposing that these pre-service ESL teachers are non-native speakers of English, it is obviously considered that they may encounter even more serious anxiety in terms of teaching a lesson, using English language in the classroom.

As Dörnyei $(1994,2001)$ and Krashen (1987) suggest, the effective language teachers are regarded to be ones who develop students' self-efficacy, decrease their anxiety, promote motivation-enhancing attributions, encourage students to set attainable sub-goals, and increase the attractiveness of course content. However, assuming that ESL teachers keep a high anxiety level during the class, it may cause much more problems related with such affective factors as confidence, motivation, self-esteem, and risk-taking ability, which ends up with losing a great interest and confidence towards language teaching (Gebhard, 1990; Young, 1991).

Therefore, this study is designed to examine a Non-Native Pre-Service ESL Teacher's (hereafter to be called: 'NNPSET') foreign language anxiety in the classroom situation throughout the teaching practicum. This study first investigates which language anxiety factors would be the most influential among NNPSETs in their practicum classroom, and then explores which language anxiety factors strongly affect NNPSETs when they conduct microteaching sessions.

\section{LITERATURE REVIEW}

\section{A. Affective Filters}

According to theory of second language acquisition by Krashen (1985), five main hypotheses are categorized; 1) Natural order hypothesis, 2) Acquisition/Learning Hypothesis, 3) Monitor Hypothesis, 4) Input Hypothesis, 5) Affective Filter Hypothesis. Among these five hypotheses, 'Affective Filter Hypothesis' focuses on affective variables identified as motivation, personality, self-confidence, self-esteem, and anxiety which play a facilitative role in foreign and second language learning. Krashen (1989) stresses that language learners with high motivation, self-confidence, and a low anxiety level are more likely to success in foreign and second language acquisition. In other words, learners with low 
motivation, low self-esteem, and a high level of anxiety are easy to face the affective filter, causing a mental barrier which keeps comprehensible input from being used for acquisition.

As a matter of fact, NNPSTs were also in the same situations once they were taught English as ESL learners, so they understand how affective filters work in the foreign and second language class, and how powerfully those filters impact in foreign and second language acquisition. After all, based on Affective Filter Hypothesis, it is significant for foreign and second language teachers to keep in mind to low affective filters of foreign and second language learners, so that these learners can maintain risk-taking behavior in regards to practicing and learning a foreign and second language.

1. Anxiety

Anxiety is thought to be a normal feeling to human beings which can be brought about by any internal or external changes, uncertain situations, or feeling of uncertainty. That is, when people face a particular situation that is not familiar with, it is natural most of them have the same feeling, that is, nervousness, and tense, which can be also considered as anxiety. To foreign language learners or teachers, an oral interview, a presentation or a speaking test in the classroom can be good examples.

Through these situations, anxiety is considered to be related to psychological symptom. A psychologist, Spielberger (as cited in Horwitz, 2001, p.123; Cubukcu, 2007, p.133), defined anxiety as, "anxiety is the subjective feeling of tension, apprehension nervousness, and worry associated with an arousal of the autonomic nervous system." Also, Hewitt (2011) defines anxiety as, "an abnormal and overwhelming sense of apprehension and fear often marked by physiological signs (as sweating, tension, and increased pulse), by doubt concerning the reality and nature of the threat, and by self-doubt about one's capacity to cope with it".

In this regard, anxiety is a psychological symptom which occurs when people feel nervous in unfamiliar situations. This cannot be expressed numerically, because it is deeply associated with feelings and emotions of human beings such as nervousness, tension, frustration, and uneasiness.

\section{B. Language Anxiety}

There have been a number of studies related to language anxiety, and language learning and teaching. Through those studies, researchers classified many types of language anxiety depending on perspectives of anxiety. Cubukcu (2007) divided anxiety into two types: a personality trait and a transient anxiety state, and it is more closed to related with a response to a particular anxiety provoking stimulus. In terms of foreign language learning and teaching, anxiety typically contains two components; one is cognitive anxiety as the mental aspect of previous anxiety experience including negative expectation, preoccupation with performance and concern about others' perception; and the other one is somatic anxiety, which refers to learners' perceptions of the physiological effects of the anxiety experience as reflected arousal and unpleasant feeling states.

MacIntyre and Gardner (1989) examined the relationship between language anxiety and other anxieties, and they classified anxiety into two categories; General Anxiety and Communication Anxiety. General Anxiety consisted of trait, state, and test anxiety, and Communication Anxiety is more related with speaking and communication situations. There is another category of anxiety, called Situational Anxiety, and it was defined by Lalonde and Gardner (as cited in MacIntyre and Gardner, 1991c). They found that this language anxiety through the test of motivation and attitude in language learning. In MacIntyre and Gardner's (1991b) study, they approached from anxiety in three perspectives. The first is a general personality trait in several situations, the second is an emotional state which was interested in the hereand-now experience of anxiety, and the last one is the specific forms of anxiety in certain given situations.

MacIntyre and Gardner (1989) found that the higher communicative anxiety students had, the slower students studied and did not remember well what they learned. They also figured out that there has been shown negative correlation between performance test results and anxiety, and they argued that foreign language anxiety affected not only output parts of speaking but also learning steps. Horwitz (2010) investigated what foreign language anxiety occurred in a foreign language classroom. They reported that when students had to cope with difficult situations, or to convey with personal messages in the class, they felt anxiety. Certain beliefs about language learning also contributed to the student's tension and frustration. ESL learners of a low level of English proficiency, for instance, have experienced more apprehension, solicitude and concern, and also had difficulty concentrating on the lesson. And such feelings made them show their avoidance behavior such as not participating in a class actively, not completing their homework, and even not attending classes.

Horwitz (1983) divided students' avoidance behavior into three major elements using Foreign Language Classroom Anxiety Scale; 1) Communication Apprehension, 2) Test Anxiety, and 3) Fear of Negative Evaluation. According to his study, students who have got higher anxiety, students have got lower their final course grades, and performance (Aida, 1994).

\section{Foreign Language Classroom Anxiety Scale (FLCAS)}

Initially created by Horwitz (1983), the Foreign Language Classroom Anxiety Scale (FLCAS) is regarded to be a situational anxiety experienced in the well-defined situation of the foreign language classroom (MacIntyre \& Gardner, 1991a, 1991b, 1994). Horwitz and Cope (1986) defined FLCAS as "a distinct complex of self-perceptions, beliefs, feelings, and behaviors related to classroom language learning arising from the uniqueness of the language learning 
process" (in Horwitz \& Young, 1991, p.31). FLCAS contains thirty three items asking about learners' language anxiety during a foreign language class which is a trait-based scale.

\section{Language Teachers' Anxiety on Teaching Practice}

Horwitz (1996) claimed that many non-native language teachers feel anxiety in their target language classroom. Even though language teachers are supposed to be high-level speakers of their target language, language mastering to them is a still on-going work to achieve, and this is why most non-native language teachers are likely to have uncomfortable moments particularly in speaking their target language.

In fact, before they begin to teach the target language, once language teachers were once language learners. Previous studies have shown that students were affected by language anxiety, non-native language teachers might also be influenced by language anxiety because they were language learners, as well.

\section{RESEARCH DESIGN}

\section{A. Setting and Participants}

The participants of this study were total fifty two NNPSETs who enrolled ESL Teacher Licensure Program at a public university located in Seoul, South Korea. As pre-service teachers, all of them participated in teaching practicum as a part of requirement to acquire ESL initial licensure. During a semester-long teaching practicum, NNPSETs were observed and monitored by the cooperating teachers each time they gave a lesson, and also by ESL supervisors from the university four times during the practicum for the evaluation of their performance. To figure out participants' background, an information questionnaire was administered prior to study.

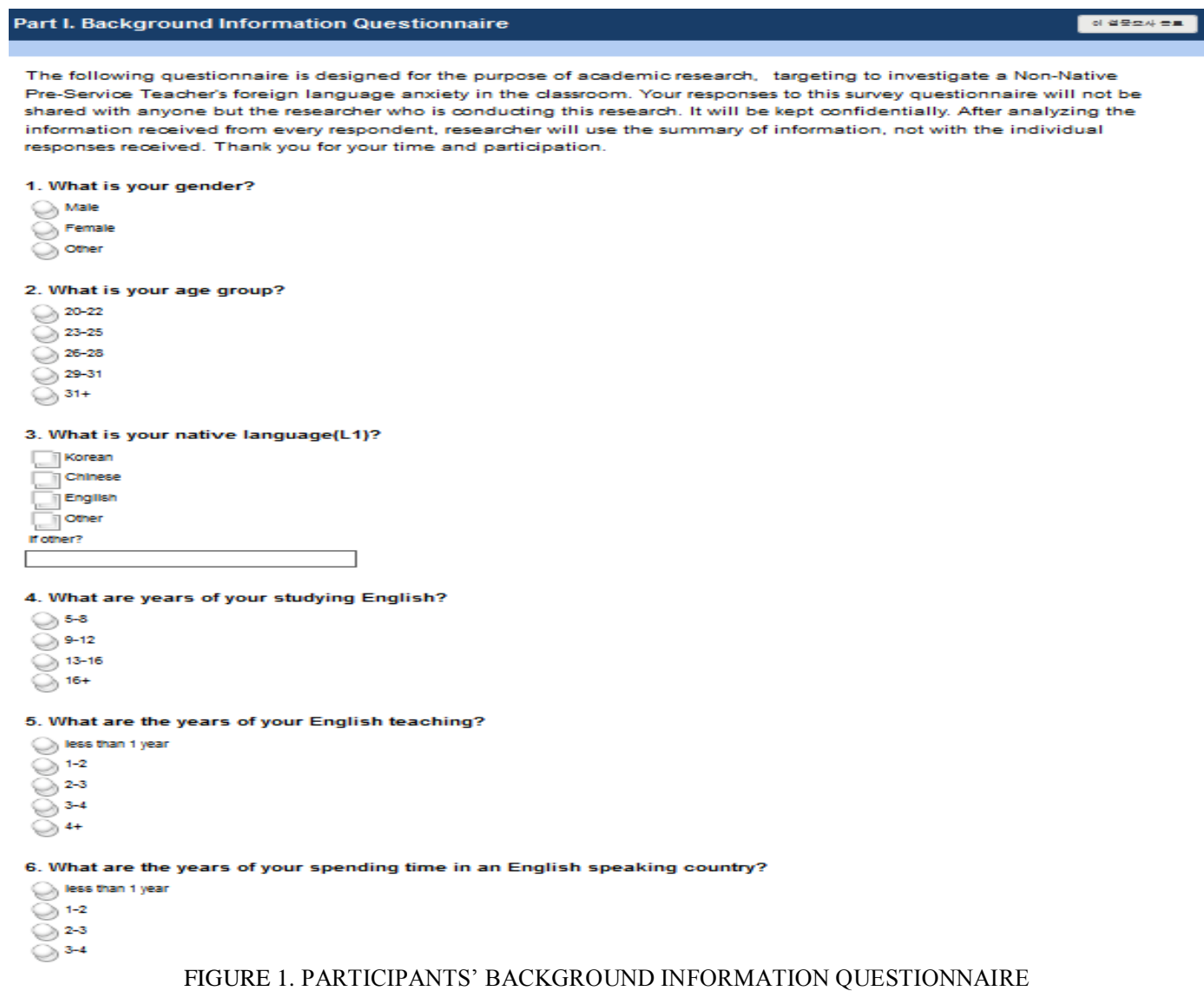

As shown in Figure 1, the format of the survey was an electronic version and the results show that 22 of 52 participants were male and the others were female. The average age of participants was 27.5, ranging from 24 to 31 . Most of the participants were in their mid-20s. Except for 3, the rest of them marked their first language (L1) as Korean. The range of teaching experience was as follows: less than 1 year $(n=23)$, between 2 year and 3 years $(n=18)$, between 4 years and 5years $(n=11)$. Also, the average time of formal English study was 12 years and, as regards amount time spent in English-speaking country, 8 responded more than 4 years, whereas average time for the rest was 1.5 years.

\section{B. Instrument}

For this study, as the first part of the survey a background information questionnaire was employed which was related to each participant's age, gender, native language, teaching experience, and length of English study. Besides, 
there was a detailed follow-up survey (Appendix 1) consisting of a 24-item Foreign Language Classroom Anxiety Scale (FLCAS). All the items were placed on a 6-point Likert scale ranging from 'strongly disagree' to 'strongly agree'. In addition to a FLCAS survey, there were two open-ended questions included at the end, which were provided to figure out the most influential factor among language anxiety as non-native pre-service ESL teachers, and to investigate the ways how to cope with it. And to gain an timely effective data, the questionnaires were all conducted through online, using 'Surveymonkey' (http://www.surveymonkey.com) which enabled the researcher to create a tailored web survey and to receive an instance result for the data analysis.

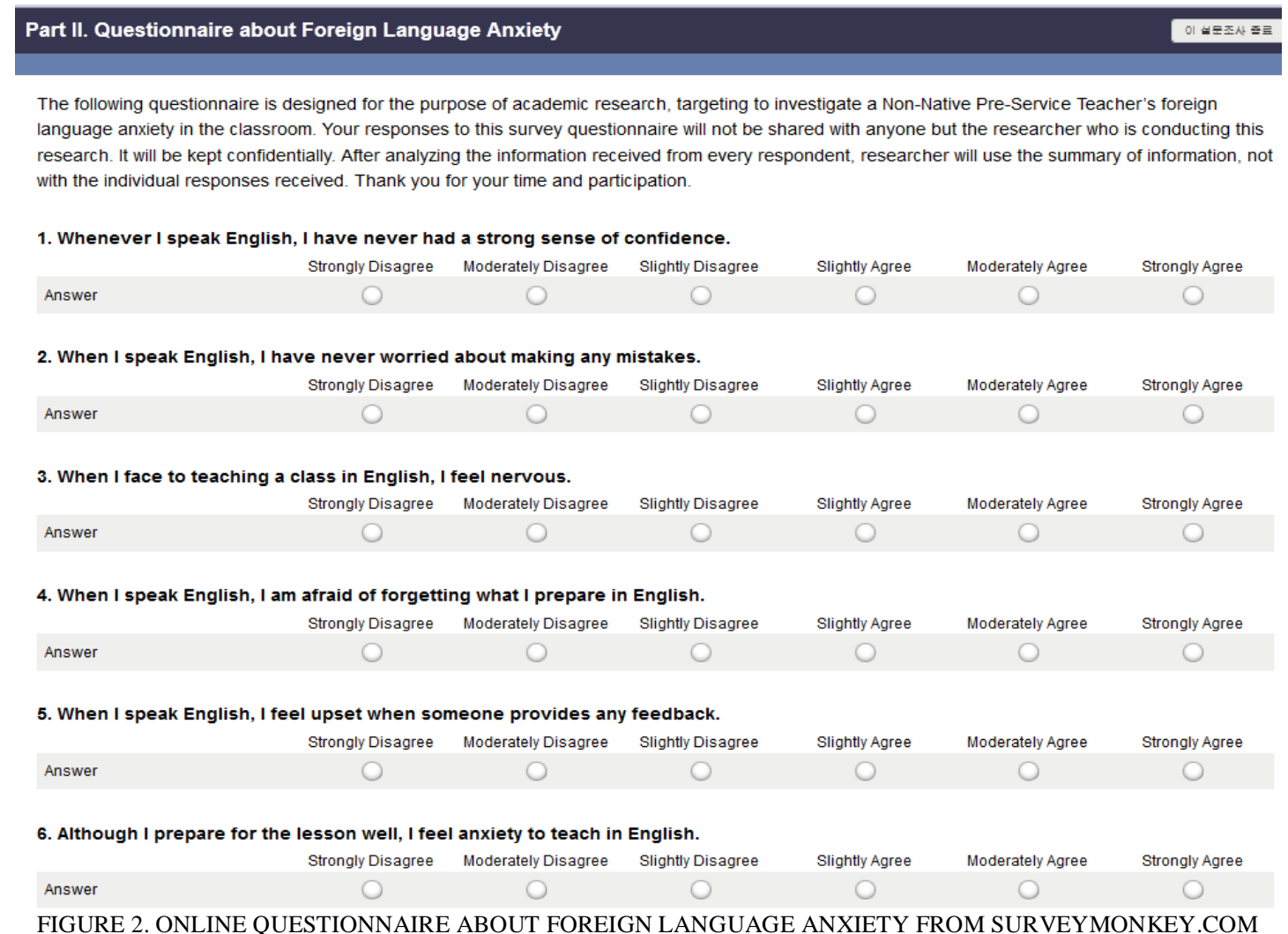

\section{Data Collection}

This questionnaire adapted from the questionnaires developed Horwitz (1983) was distributed to all participants through online, and it contained 24 statements with which NNPSETs were asked to indicate whether they agreed or disagreed. And then, descriptive statistics were used in order to report the results of the questionnaire. In addition to quantitative data, the qualitative data for the study was obtained from two open-ended questions instead of having faceto-face interviews. To facilitate the process of eliciting supporting data, two carefully constructed questions were added, and each question contained a set of issues aimed at eliciting further information from the participants.

\section{Data Analysis}

In order to find factors which could describe individual NNPSETs' characteristics in the classroom,, the Principal Component and principal axis factoring tools which was followed by Varimax rotation performed using the statistical tool, IBM SPSS Statistics (version 19), and it was designed to calculate nearly identical results in terms of how the items were clustered. And simplistic statistics such as percentage, means, standard deviation, and comparing several means were used to analyze the survey results. In terms of analyzing the qualitative data gathered from two open-ended questions, the data were coded, and then categorized. The data obtained from both questionnaires and open-ended questions were constantly compared and contrasted before conclusions were made.

\section{RESULTS}

The online survey questionnaire was used to determine the underlying structure of the concept of language anxiety measured by modified version of FLCAS. Twenty-four items on the survey were asked using a six-point Likert scale ranging from 'strongly agree (6)' to 'strongly disagree (1). When this questionnaire was administered, possible scores were in the range of 23 to 138. Descriptive statistics for the questionnaire is presented in Table 1 . The item 23 shows the lowest mean, 1.9341, whereas, the item 19 shows the highest mean, 4.3721. And standard deviations vary small ranging from 1.09042 to 1.60472 . 
TABLE 1.

DESCRIPTIVE STATSTICS FOR THE LANGUAGE ANXIETY AS NNPSETS IN THE CLASS

\begin{tabular}{|l|l|l|}
\hline Items & Means & Standard Deviation \\
\hline B-1 & 2.2013 & 1.15236 \\
\hline B-2 & 3.6239 & 1.33561 \\
\hline B-3 & 2.3501 & 1.17992 \\
\hline B-4 & 2.3329 & 1.25724 \\
\hline B-5 & 2.3233 & 1.50081 \\
\hline B-6 & 2.4249 & 1.30304 \\
\hline B-7 & 2.7648 & 1.39250 \\
\hline B-8 & 3.6984 & 1.25254 \\
\hline B-9 & 2.6667 & 1.33199 \\
\hline B-10 & 2.2381 & 1.14602 \\
\hline B-11 & 2.5714 & 1.18749 \\
\hline B-12 & 2.2063 & 1.19351 \\
\hline B-13 & 2.7460 & 1.48072 \\
\hline B-14 & 2.5079 & 1.35448 \\
\hline B-15 & 2.1905 & 1.09042 \\
\hline B-16 & 3.2859 & 1.48106 \\
\hline B-17 & 2.2698 & 1.43916 \\
\hline B-18 & 2.5052 & 1.29357 \\
\hline B-19 & 4.3721 & 1.40768 \\
\hline B-20 & 2.1032 & 1.26960 \\
\hline B-21 & 3.9105 & 1.60472 \\
\hline B-22 & 4.1254 & 1.49774 \\
\hline B-23 & 1.9341 & 1.22965 \\
\hline B-24 & 2.3142 & 1.41327 \\
\hline & & \\
\hline
\end{tabular}

For the present study, the researcher conducted the principal axis factor tools, and examined the scree plot. As can be seen the Table 2 below, Varimax procedure was converged in 7 repetition, and 4 factors were shown with eigen values of 9.259 (Factor 1), 2.142 (Factor 2), 1.719 (Factor 3), and 1.260 (Factor 4). Among those twenty-four items, only two items in the present survey which was modified and used, did not load on any one factor (items\# 11, 21). These items were those with loading less than .5. Consequently, the subsequent analysis resulted in a four-factor solution, explaining about 62.523 of the total variance. Along with communalities, the factor pattern matrix with the four-factor solution and the percentage of the total variance accounted for this solution are presented in below Table 2. 
TABLE 2.

FACTOR ANALYSIS SUMMARY

\begin{tabular}{|c|c|c|c|c|}
\hline \multirow[t]{2}{*}{ Items } & \multicolumn{4}{|l|}{ Factors } \\
\hline & $\begin{array}{l}\text { 1. Language anxiety on } \\
\text { using English in the class }\end{array}$ & $\begin{array}{l}\text { 2. Language anxiety } \\
\text { based on self-confidence }\end{array}$ & $\begin{array}{l}\text { 3. Language anxiety } \\
\text { about class preparation }\end{array}$ & $\begin{array}{l}\text { 4. Language anxiety } \\
\text { overcome with efforts }\end{array}$ \\
\hline B-1 & .286 & .220 & .576 & .095 \\
\hline B-3 & .203 & .052 & .783 & -.019 \\
\hline B-4 & .170 & -.005 & .866 & .075 \\
\hline B-7 & .544 & .185 & .059 & .364 \\
\hline B-8 & -.079 & -.784 & -.129 & .197 \\
\hline B-9 & .306 & .657 & .329 & -.042 \\
\hline B-10 & .659 & .132 & .235 & -.155 \\
\hline B-11 & .314 & .449 & .321 & -.162 \\
\hline B-12 & .753 & .331 & .295 & -.011 \\
\hline B-16 & -.091 & .029 & .335 & .756 \\
\hline B-17 & .682 & .306 & .281 & -.071 \\
\hline B-18 & .708 & .446 & .021 & .223 \\
\hline B-19 & -.660 & -.015 & .020 & 435 \\
\hline $\mathrm{B}-20$ & .786 & .165 & .152 & -.119 \\
\hline B-21 & -.274 & -.409 & .097 & .072 \\
\hline B-22 & -.164 & .329 & -.164 & .697 \\
\hline B-23 & .736 & .274 & .096 & -.199 \\
\hline B-24 & .524 & .190 & .121 & .308 \\
\hline Eigen Value $\%$ & 9.259 & 2.142 & 1.719 & 1.260 \\
\hline Variation Cum. \% & 40.225 & 9.313 & 7.475 & 5.480 \\
\hline
\end{tabular}

As a step in labeling the factors extracted, the content analysis of the items clusters against each factor was followed. At the same time, the factor structure matrix and the factor pattern matrix were compared with others. As below Table 4 shows, twelve items (item\# 5, 7, 10, 12, 13, 14, 15, 17, 18, 20, 23, 24) with factor loading greater than .5 were clustered into Factor 1. This Factor 1 shows the most influential factor among four factors extracted. These items identified the scope of teachers' using English language anxiety related with. It is named as 'language anxiety on using English in the class factor'. Because they are lack of confidence, teachers are concerned with making mistakes in general and in front of their students in language class. Factor 1 can be separated into 2 big categories, as well; the first one is speaking English, and the second is about speaking English in front of the class as a language teacher. This category is the most influential factor of NNPSETs' language anxiety on the English classroom. Even though they are language teachers, they feel a lot of stress and emotional pressures by language anxiety through this cluster.

TABLE 3.

FACTOR 1: LANGAUGE ANXIETY ON USING ENGLISH IN THE CLASS

\begin{tabular}{|l|l|}
\hline Items & Statements \\
\hline B-5 & I am nervous that someone recognizes mistakes I make. \\
\hline B-7 & I often feel uncomfortable to speak English, even though I majored it. \\
\hline B-10 & The more I prepared for speaking English, the more confused I get. \\
\hline B-12 & I sometimes feel it is difficult to speak English in front of students in class. \\
\hline B-13 & I feel anxiety of making any mistakes in front of students in class. \\
\hline B-14 & I feel nervous when students in the class do not understand my English. \\
\hline B-15 & I feel overwhelmed by the number of rules you have to learn to speak English \\
\hline B-17 & I feel more tense and nervous when English class starts. \\
\hline B-18 & I feel panic when my students do not react on what I teach English. \\
\hline B-19 & I sometime recognize my mistakes, and try not to make the same mistake next time. \\
\hline B-20 & I am embarrassed to talk to native speakers of English. \\
\hline B-23 & I am thinking too much of not making any mistakes while speaking English \\
\hline
\end{tabular}

As can be seen from Table 4, Factor 2 characterizes an aspect of how much NNPSETs feel confident when they speak English. These three items mean that participants of this study felt language anxiety with their degree of the selfconfidence while they were talking with foreigners. According to this, Factor 2 is classified as 'language anxiety depending on the self-confidence factor.'

TABLE 4.

FACTOR 2: LANGUAGE ANXIETY BASED ON SELF-CONFIDENCE

\begin{tabular}{|l|l|}
\hline Items & Statements \\
\hline B-2 & I don't care too much about making any mistakes in speaking English. \\
\hline B-8 & I feel comfortable when I speak English. \\
\hline B-9 & I can feel my heart beating fast whenever I speak English. \\
\hline
\end{tabular}


As displayed in Table 5, Factor 3 is composed of 5 items (item\# 1, 3, 4, 6, and 24), and each five statement is closely related to their fear when they have to face with speaking or teaching English in the classroom. Therefore, these items are named as 'language anxiety about the class preparation factor.'

TABLE 5 .

FACTOR 3: LANGUAGE ANXIETY ABOUT CLASS PREPARATION

\begin{tabular}{|l|l|}
\hline Items & Statements \\
\hline B-1 & I feel confident when I speak English to teach a lesson. \\
\hline B-3 & I feel tense when I have to teach a lesson in English. \\
\hline B-4 & I am afraid that I forget things I prepared for classes in English. \\
\hline B-6 & Though I am prepared for a lesson, I always feel anxious about speaking English. \\
\hline B-24 & If I may teach English in L1, I think I can do it much better. \\
\hline
\end{tabular}

Table 6 shows that Factor 4 (item\# 16, 22) explains the reaction to their anxiety while they speak English. Participants of the present study showed the feeling of satisfaction when they thought they spoke English well, and this fact led them to overcome language anxiety while they were talking in English. Thus, this Factor 4 is identified as 'NNPSETs' efforts to overcome language anxiety factor.'

TABLE 6

FACTOR 4: LANGUAGE ANXIETY OVERCOME WITH EFFORTS

\begin{tabular}{|l|l|}
\hline Items & Statements \\
\hline B-16 & I feel confident when I speak English to teach a lesson. \\
\hline B-22 & I try to overcome anxiety whenever I speak English. \\
\hline
\end{tabular}

The result of two open-ended questions shows that 52 NNPSETs had a common thought about having experienced language anxiety in various situations. In the Table 7 below, there are examples of all the answers categorized into five groups of answers. There were a variety of answers, but most of respondents had common opinions which they were not confident to speak and use English because their native language is not English. They also felt anxiety when their students did not understand what they spoke in English. But a majority of respondents frequently felt apprehension whenever they made mistakes while conducting a micro-teaching as a language teacher.

TABLE 7.

RESPONSES TO THE LANGUAGE ANXIETY IN THE LANGUAGE CLASS

\begin{tabular}{|l|l|l|}
\hline Statements & $\begin{array}{l}\text { Response } \\
\text { (count) }\end{array}$ & $\begin{array}{l}\text { Response } \\
\text { (percent) }\end{array}$ \\
\hline $\begin{array}{l}\text { Because I am not a non-native speaker of English, I am worried about pronunciation, } \\
\text { intonation, stress, and so on. }\end{array}$ & 48 & $92.3 \%$ \\
\hline $\begin{array}{l}\text { I want to be an ESL teacher, but I am pressured to make a mistake while speaking } \\
\text { English in front of my students. In addition, there are some students who have learned } \\
\text { English as L1, so it gives me more pressure and stress, preventing me from making } \\
\text { any mistakes. }\end{array}$ & 46 & $88.4 \%$ \\
\hline $\begin{array}{l}\text { I want to have more opportunities and experiences to practice English teaching } \\
\text { through English even after the teaching practicum. }\end{array}$ & 38 & $73.1 \%$ \\
\hline $\begin{array}{l}\text { I do not feel language anxiety, but I feel strong language anxiety when I stand in front } \\
\text { of the students in the class, because I may make mistakes. But if students are very } \\
\text { supportive, I gain confidence to speak English. }\end{array}$ & 34 & $65.4 \%$ \\
\hline $\begin{array}{l}\text { I wonder what would be the best way to teach English to ESL learners. To speak only } \\
\text { English in the class may not be a solution. }\end{array}$ & 31 & $59.7 \%$ \\
\hline
\end{tabular}

\section{CONCLUSIONS}

This study has sought to examine which language anxiety factors influence to NNPSETs when they face to speak and teach English through English in their practicum classes. And in order to find out those factors, a survey questionnaire was employed, and the results of this research are in accordance with findings from literature reviews on the types of language anxiety. The data resulted from the survey showed that NNPSETs felt difficulties in teaching through English, followed by lack of self-confidence about English, and its anxiety about using English in their ESL practicum classes. Based on the language anxiety factors they felt, four factors were categorized as a finding, which are the fear of English speech in the classroom (Factor 1), language anxiety depending on the self-confidence (Factor 2), language anxiety about the class preparation (Factor 3), and NNPSETs' efforts to overcome language anxiety (Factor 4).

Such findings may lead to a conclusion that NNPSETs should be trained to have more self-confidence and less anxiety to conduct a micro-teaching, or any classroom teachings, using English. For instance, it is highly recommended to provide exclusive English training classes for NNPSETs in ESL licensure program, which may help to control their emotional and affective factors with support from current faculty members in the teacher education program.

And it is also suggested that skillful ESL faculty members through exclusive English training classes can sustain NNPSETs based on their previous Know-Hows, guiding them to become effective ESL teachers who would overcome language anxiety. In addition to exclusive English program, to run a mentoring language program with native pre- 
service ESL teachers (NPSET) can be beneficial to NNPSETs in that by communicating, learning and teaching collaboratively and interpersonally, as a team, NNPSETs can lower their anxiety level, accustoming themselves to English language and its teaching.

\section{APPEDIX A. SURVEY QUESIONNAIRE}

The actual survey is formatted differently from this document, in which the response options are simply on a clicking basis using a computer or any electronic devices.

The following questionnaire is designed for the purpose of academic research, targeting to investigate a Non-Native Pre-Service Teacher's foreign language anxiety in the classroom. Your responses to this survey questionnaire will not be shared with anyone but the researcher who is conducting this research. It will be kept confidentially, and after analyzing the information received from every respondent, researcher will use the summary of information, not with the individual responses received. Thank you for your time and participation.

Part I. Personal Background Information

\begin{tabular}{|l|l|}
\hline Gender & Male ( ) Female ( ) Other ( ) \\
\hline Age group & $20-22$ ( ) 23-25 ( ) 26-28 ( ) 29-31 ( ) 31+ ( ) \\
\hline Native language(s) & Korean ( ) Chinese ( ) English ( ) Other ( ) \\
\hline Years of formal English study & $5-8$ ( ) 9-12 ( ) 13-16 ( ) 16+ ( ) \\
\hline Years of teaching English & Less than 1 year ( ) 1-2 ( ) 2-3 ( ) 3-4 ( ) $4+($ ( ) \\
\hline Years of time spent in English-speaking countries & Less than 1 year ( ) 1-2 ( ) 2-3( ) 3-4 ( ) $4+($ ) \\
\hline
\end{tabular}

Part II. Questionnaire about Foreign Language Anxiety

\begin{tabular}{|c|c|c|c|c|c|c|c|}
\hline \multirow[t]{2}{*}{$\begin{array}{l}\text { Item } \\
\#\end{array}$} & \multirow[t]{2}{*}{ Questions } & $\begin{array}{l}\text { Strongly } \\
\text { Disagree }\end{array}$ & $\begin{array}{l}\text { Moderately } \\
\text { Disagree }\end{array}$ & $\begin{array}{l}\text { Slightly } \\
\text { Disagree }\end{array}$ & $\begin{array}{l}\text { Slightly } \\
\text { Agree }\end{array}$ & $\begin{array}{l}\text { Moderately } \\
\text { Agree }\end{array}$ & $\begin{array}{l}\text { Strongly } \\
\text { Agree }\end{array}$ \\
\hline & & 1 & 2 & 3 & 4 & 5 & 6 \\
\hline 1 & $\begin{array}{l}\text { Whenever I speak in English, I have never had a strong } \\
\text { sense of confidence. }\end{array}$ & & & & & & \\
\hline 2 & $\begin{array}{l}\text { When I speak English, I have never worried about } \\
\text { making any mistakes. }\end{array}$ & & & & & & \\
\hline 3 & When I face to teaching a class in English, I feel nervous. & & & & & & \\
\hline 4 & $\begin{array}{l}\text { When I speak English, I am afraid of forgetting what I } \\
\text { prepare in English. }\end{array}$ & & & & & & \\
\hline 5 & $\begin{array}{l}\text { When I speak English, I feel upset when someone } \\
\text { provides any feedback. }\end{array}$ & & & & & & \\
\hline 6 & $\begin{array}{l}\text { Although I prepare for the lesson well, I feel anxiety to } \\
\text { teach in English. }\end{array}$ & & & & & & \\
\hline 7 & At times, I hesitate to speak English. & & & & & & \\
\hline 8 & I feel very comfortable in speaking English. & & & & & & \\
\hline 9 & When I speak English, I feel very nervous. & & & & & & \\
\hline 10 & $\begin{array}{l}\text { The more I prepare for English class, the more nervous I } \\
\text { become }\end{array}$ & & & & & & \\
\hline 11 & $\begin{array}{l}\text { When I speak English, I feel so nervous that I may forget } \\
\text { what I've got to know. }\end{array}$ & & & & & & \\
\hline 12 & When I speak English in front of students, I feel nervous. & & & & & & \\
\hline 13 & $\begin{array}{l}\text { When I speak English, I am afraid of making any } \\
\text { mistakes. }\end{array}$ & & & & & & \\
\hline 14 & $\begin{array}{l}\text { When speaking English in class, I feel tension and } \\
\text { frightened. }\end{array}$ & & & & & & \\
\hline 15 & When I speak English, my heart will beat faster · & & & & & & \\
\hline 16 & $\begin{array}{l}\text { When I speak English, I try to overcome such feeling of } \\
\text { anxiety. }\end{array}$ & & & & & & \\
\hline 17 & I always feel anxiety in every micro-teaching session. & & & & & & \\
\hline 18 & $\begin{array}{l}\text { When I do a micro-teaching, I feel very anxiety when } \\
\text { students understand the lesson. }\end{array}$ & & & & & & \\
\hline 19 & $\begin{array}{l}\text { I am aware of my mistakes while speaking English and } \\
\text { try to practice not to make same mistakes. }\end{array}$ & & & & & & \\
\hline 20 & When I speak English to a native speaker, I feel nervous. & & & & & & \\
\hline 21 & $\begin{array}{l}\text { When I speak English to a non-native speaker, I feel } \\
\text { comfortable. }\end{array}$ & & & & & & \\
\hline 22 & $\begin{array}{l}\text { When I speak English, I think my English should be } \\
\text { perfect. }\end{array}$ & & & & & & \\
\hline 23 & $\begin{array}{l}\text { When I realize I have made a mistakes, I become more } \\
\text { nervous }\end{array}$ & & & & & & \\
\hline 24 & $\begin{array}{l}\text { If I speak L1 in the class, I can teach English better than } \\
\text { use English. }\end{array}$ & & & & & & \\
\hline
\end{tabular}

Part III. Personal Opinions about Foreign Language Anxiety 
Q1. As a pre-service ESL teacher, what do you think the most influential anxiety factors are, in terms of teaching in English and speaking English in the class?

Q2. What do you, as a language teacher think the better ways would be to overcome foreign language anxiety in ESL classroom?

\section{REFERENCES}

[1] Aida, Y. (1994). Examination of Horwitz, Horwitz, and Cope's construct of foreign language anxiety: The case of students of Japanese. The Modern Language Journal, 78(2),155-168.

[2] Cubukcu, F. (2007). Foreign language anxiety. Iranian Journal of Language Studies, 1(2), 133-142.

[3] Dörnyei, Z. (1994). Motivation and motivating in the foreign language classroom. Modern Language Journal, 78, $273-284$.

[4] Dörnyei, Z. (2001). Teaching and research motivation. London: Pearson Education Limited.

[5] Gebhard, J. G. (1990). Interaction in a teaching practicum. In J. C. Richards \& D. Nunan (Eds.). Second language teacher education (pp. 118-131). New York: Cambridge University Press.

[6] Hewitt, L. (2011). In Merriam-Webster.com. Retrieved May 8, 2011, from http://www.merriamwebster.com/dictionary/anxiety

[7] Horwitz, E. K. (1983). Foreign language classroom anxiety scale. Unpublished. manuscript, University of Texas, Austin.

[8] Horwitz, E. K. (1988). The beliefs about language learning of beginning university foreign language students. Modern Language Journal, 72(3), 283-294.

[9] Horwitz, E. K. (1996). Even teachers get the blues: Recognizing and alleviating language teachers' feelings of foreign language anxiety. Foreign Language Annals, 29(3), 365-372.

[10] Horwitz, E. K. (2001). Language anxiety and achievement. Annual Review of Applied Linguistics, 21, 112-126.

[11] Horwitz, E. K. (2010). Foreign and second language anxiety, Language Teaching, 43(2), 154-167.

[12] Horwitz, E. K., Horwitz, M. B., \& Cope, J. (1986). Foreign language classroom anxiety. The Modern Language Journal, 20(2), $125-132$.

[13] Horwitz, E. K., \& Young, D. J. (1991). Language anxiety: From theory and research to classroom implications. Englewood Cliffs, NJ: Prentice Hall.

[14] Huang, S., Eslami, Z., \& Hu, R. (2010). The relationship between teacher and peer support and English-language learners' anxiety, English Language Teaching, 3(1), 32-40.

[15] Hussain, M., Shahid, S., \& Zaman, A. (2011). Anxiety and attitude of secondary school students towards foreign language learning, Social and Behavioral Sciences, 29, 583-590.

[16] Krashen, S. (1989). Language acquisition and language education: extensions and applications, New York: Prentice-Hall International.

[17] Krashen, S. (1985). The Input hypothesis: Issues and implications, London: Longman.

[18] Krashen, S. (1987). Principles and practice in second language acquisition. New York: Prentice-Hall International

[19] Liu, M., \& Jackson, J. (2008). An exploration of Chinese EFL learners' unwillingness to communicative and foreign language anxiety. The Modern Language Journal, 92, 71-86.

[20] Liu, M., \& Zhang, W. (2010). Affective and cognitive factors and foreign language achievement. B. C., Victoria: Traffold Publishing.

[21] MacIntyre, P. D. (1995). How does anxiety affect second language learning? A reply to sparks and ganschow. Modern Language Journal, 79(1), 90-99.

[22] MacIntyre, P. D. \& Gardner, R. C.(1989). Anxiety and second language learning: Toward a theoretical clarification. Language Learning, 39, 251-275.

[23] MacIntyre, P. D. \& Gardner, R. C. (1991a). Investigating language class anxiety using the focused Essay Technique. Modern Language Journal, 75, 296-304.

[24] MacIntyre, P. D. \& Gardner, R. C. (1991b). Methods and results in the study of anxiety and language learning: A Review of the Literature. Language Learning, 41(1), 85-117.

[25] MacIntyre, P. D \& Gardner, R. C. (1994). The subtle effects of language anxiety on cognitive processing in the second language. Language Learning, 44(2), 283-305.

[26] Ohata, K. (2005). Language anxiety from the teacher's perspective: interviews with seven experienced ESL/EFL Teachers, Journal of Language and Learning, 3(1), 133-155.

[27] Spielberger, C. D. (1972). Anxiety: Current trends in theory and research: I. New York, N.Y.: Academic Press.

[28] Spielberger, C. D. (1980). Test Anxiety Inventory. Preliminary professional manual. Palo Alto, CA: Consulting Psychologists Press.

[29] Young, D. J. (1991). The Relationship between anxiety and foreign language oral proficiency ratings. In Horwitz, E. and Young, D. (Eds.). Language anxiety: From theory and research to classroom implications (pp57-63). Englewood Cliffs, NJ: Prentice-Hall.

Tecnam Yoon is currently an Ed.D. candidate in Language, Literacy \& Culture concentration, Department of Teacher Education and Curriculum Studies at the University of Massachusetts, Amherst. Prior to joining the doctoral program, he was a middle school English teacher and experienced teaching ESP course to college students. 